\title{
Organic Amendments and Earthworm Addition Improve Properties of Nonacidic Mine Tailings
}

\author{
P. M. Rutherford and J. M. Arocena \\ Environmental Science and Engineering Program, University of Northern British Columbia, 3333 University Way, Prince George, \\ BC, Canada V2N $4 Z 9$ \\ Correspondence should be addressed to P. M. Rutherford, rutherfm@unbc.ca
}

Received 15 June 2011; Revised 25 August 2011; Accepted 7 September 2011

Academic Editor: Giuseppe Corti

Copyright ( 2012 P. M. Rutherford and J. M. Arocena. This is an open access article distributed under the Creative Commons Attribution License, which permits unrestricted use, distribution, and reproduction in any medium, provided the original work is properly cited.

\begin{abstract}
In many mined areas, lack of topsoil limits conversion of disturbed landscapes to former or other productive uses. We examined the use of biosolids ( 10 or $20 \%$ by dry mass), with or without sawdust, pulp sludge, and the contribution of an earthworm species (Dendrobaena veneta) to improve the properties of nonacidic mine tailings. Pulp sludge more rapidly immobilized excessive $\mathrm{NH}_{4}{ }^{+}$ concentrations from biosolids early in the study; however, total mineral $\mathrm{N}$ concentrations were similar in pulp sludge and sawdust treatments by week 29. Although $\mathrm{NO}_{3}{ }^{-}-\mathrm{N}$ concentrations were generally greater in treatments with earthworms, these trends were not statistically significant $(P>0.05)$. In general, Bray $\mathrm{P}$ concentrations were greater in the presence of earthworms. Soil thin sections showed that earthworms mixed organic residues into elongated spherical units within mine tailings. Organic residues in combination with earthworm addition may improve the chemical and microstructural properties of non-acidic mine tailings, producing a substrate conducive for plant establishment.
\end{abstract}

\section{Introduction.}

Mining operations around the world produce large quantities of residuals such as tailings, overburden, and waste rock. Past mineral extractions in the Sierra de Cartagena (SE Spain) for $>2,500$ years left behind large volumes (i.e., usually $700,000-900,000 \mathrm{~m}^{3}$ per deposit) of wastes composed of overburden rocks and tailings [1]. A copper and gold mine in northern British Columbia (Canada) generated nearly 25 million tonnes of milled waste rock in 2007 [2]. In Canada and other jurisdictions, industry is required to convert disturbed landscapes to former or other productive uses following mine extraction and processing activities. High-quality topsoil is often limiting at mine sites, so mines often need to utilize on-site substrates (such as mine tailings) to create mine soils for reclamation activities.

Establishment of vegetation is key to reclamation of mine tailings and other residuals [2-5]. Plant cover minimizes the dispersion of particulate matter and contaminants through wind and water erosion, and improves the aesthetic value of unvegetated landscapes $[6,7]$. However, mine soils require suitable physical and chemical properties in order to support the growth of plants and associated soil organisms. Tailings are typically fine sands low in organic matter and plant available macronutrients such as $\mathrm{N}$ and $\mathrm{P}$.

Various industrial, environmental, and municipal waste treatment facilities generate organic materials that can be added to mine residuals to increase soil organic matter (SOM) and/or nutrient contents [8-12]. Biosolids, also called sewage sludges, are particularly well suited for this purpose due to their relatively high $\mathrm{N}$ and $\mathrm{P}$ contents $[10,13]$. The addition of organic residues to mine soils accelerates soil forming processes, and this practice is also a means of promoting carbon sequestration through the conversion of waste substrates into SOM $[12,14]$. Plant-derived organic inputs also contribute to SOM and play an important role in initiating soil development $[15,16]$.

In natural soils, pedogenic mixing of inorganic and organic materials is best achieved by soil organisms, particularly soil invertebrate ecosystem engineers [17]. Earthworms 
intimately mix organic and inorganic materials into soil aggregates through ingestion and excretion [18, 19]. Earthworms have also been reported to stimulate soil microbial activity and enhance the availability of soil nutrients such as nitrogen and phosphorus [17, 20,21]. Earthworms have the potential to enhance the reclamation mine residuals, but even nonacidic mine residuals provide a hostile environment to these sensitive animals [22]. The addition of organic materials may help overcome these limitations by providing an energy source, enhancing nutrient levels, stimulating microbial activity, promoting soil structural development, and increasing water-holding capacity $[22,23]$.

Addition of biosolids to mine tailings (or to other inorganic substrates) can lead to high concentrations of $\mathrm{NH}_{4}{ }^{+}$/ $\mathrm{NH}_{3}$, which is toxic to earthworms at relatively low concentrations [24]. The coapplication of high $\mathrm{C} / \mathrm{N}$ ratio organic substrates with biosolids may provide the benefit of net $\mathrm{NH}_{4}{ }^{+}-\mathrm{N}$ immobilization into the microbial biomass; this organic $\mathrm{N}$ can then undergo slow net $\mathrm{N}$ mineralization over a period of time. Addition of these supplementary substrates may have additional benefits of enhancing soil physical and chemical properties relative to tailings only receiving biosolids.

The primary objective of this 29-week laboratory study was to determine the influence of pulp sludge or softwood sawdust coapplied with biosolids on selected chemical and physical properties of nonacidic mine tailings. A secondary objective was to test the role of an earthworm species (Dendobaena veneta) for altering the selected physical and chemical properties of these amended mine tailings. Although Dendobaena veneta is considered to be an epigeic earthworm, we selected this species because it is hardy and has been shown to be active in mineral soils, including those containing organic or inorganic contaminants [25]. It is also widely used in vermicomposting and is readily available. To the best of our knowledge no studies have reported the use of this earthworm in the treatment of mine tailings.

\section{Materials and Methods}

2.1. Collection and Characterization of Substrate Materials. Inorganic and organic materials were obtained from industrial and municipal sources in north central BC (Canada). Desulphurized mine tailings were obtained from the Mount Polley copper mine near Likely, BC; anaerobically digested sewage sludge (BC Class B biosolids) was obtained from the Prince George municipal wastewater treatment facility; softwood sawdust (mainly from pine) was obtained from a local sawmill; pulp mill sludge was obtained from the Canfor Intercon Kraft pulp mill, Prince George, BC. Materials were allowed to air-dry for several weeks on plastic sheets prior to use in this study.

Substrates were well homogenized prior to characterization. Mine tailings were subjected to the following chemical analyses: total $\mathrm{C}, \mathrm{N}$, and $\mathrm{S}$ (dry combustion), total $\mathrm{P}$, and total elemental analyses using a combination of lithium metaborate fusion followed by ICP-AES (major elements), lithium borate fusion followed by ICP-MS (trace elements) and $1: 1$ concentrated $\mathrm{HNO}_{3}: \mathrm{HCl}$ digestion followed by ICP-MS $(\mathrm{Hg}, \mathrm{Se})$. Organic substrates were homogenized and subjected to the following chemical analyses: total $\mathrm{C}, \mathrm{N}$, and $\mathrm{S}$ (dry combustion), total $\mathrm{P}$ (microwave digestion followed by ICP OES), extractable $\mathrm{NH}_{4}{ }^{+}-\mathrm{N}$ and $\mathrm{NO}_{3}{ }^{-}-\mathrm{N}$ via $\mathrm{KCl}$ extraction followed by AutoAnalyzer [26]. Elements were determined by digestion in $1: 1$ concentrated $\mathrm{HNO}_{3}: \mathrm{HCl}$ followed by ICP-OES (metals, metalloids) or cold-vapor atomic fluorescence spectrophotometry (Hg). X-ray diffraction (XRD) and elemental concentrations were used to estimate $( \pm 5 \%)$ the mineralogy of the tailings. Particle size distribution of the mine tailings was determined by dry sieving [27].

As expected, concentrations of total $\mathrm{N}\left(4.95{\left.\mathrm{~g} 100 \mathrm{~g}^{-1}\right)}^{-1}\right.$

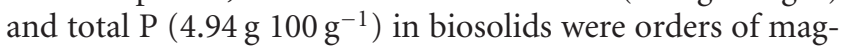
nitude greater than those in sawdust, pulp mill sludge, and mine tailings (Table 1). Ammonium- $\mathrm{N}, \mathrm{NO}_{3}{ }^{-}-\mathrm{N}$ and Bray$\mathrm{P}$ in biosolids were 2490, 2.7, and $3042 \mathrm{mg} \mathrm{kg}^{-1}$, respectively, immediately prior to use in this study; concentrations in pulp sludge and sawdust were negligible (data not shown).

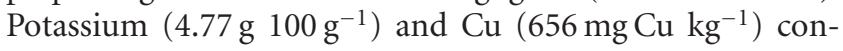
tents in mine tailings were much higher than organic substrates (Table 1). Semiquantitative estimates of the mineral composition of the tailings (via XRD and elemental composition) were $8.5 \%$ kaolinite, $2.3 \%$ goethite, $0.6 \%$ clinochlore, $1 \%$ quartz, $9.5 \%$ calcite, $0.4 \%$ muscovite, $77 \%$ feldspars, and $0.6 \%$ ilmenite. Particle size analysis of mine tailings showed the following proportions of size classes by mass (mean; standard deviation in brackets) $<63 \mu \mathrm{m}-12(3.8) \%, 63-$ $125 \mu \mathrm{m}-58(5.4) \%, 125-250 \mu \mathrm{m}-26(3.7) \%, 250-500 \mu \mathrm{m}$ $-3(0.9) \%, 500-1000 \mu \mathrm{m}-0.8(0.4) \%$, and $>1000 \mu \mathrm{m}-0 \%$.

2.2. Experimental Setup and Treatments. The experimental design consisted of 2 levels of earthworm addition (with and without) and 8 combinations of organic materials added to mine tailings (Table 2). There were three replications for each treatment (i.e., a total of 48 experimental units). Each mixture was contained within a 4 -L white plastic bucket $(19 \mathrm{~cm} \varnothing \times 15 \mathrm{~cm}$ height $)$ that had $\sim$ forty $2 \mathrm{~mm}$ holes drilled on its wall to maintain sufficient aeration. Mine tailings were added at a rate of $1500 \mathrm{~g}$ (equivalent oven-dry basis) to each container with the appropriate amounts of organic substrates. Moisture content was adjusted to $75 \%$ of water-holding capacity (WHC; see below) with tap water and the experimental units were incubated at $20^{\circ} \mathrm{C}$ for 7 weeks prior to earthworm addition to appropriate experimental units (Table 2). A plastic lid (with $\sim$ thirty $2 \mathrm{~mm}$ holes) covered each bucket during incubation to minimize water evaporation. The 7-week incubation was conducted to stimulate microbial activity and to encourage net immobilization of $\mathrm{NH}_{4}{ }^{+}-\mathrm{N}$ that originated from the biosolids prior to the addition of earthworms. As mentioned above, high concentrations of $\mathrm{NH}_{4}{ }^{+} / \mathrm{NH}_{3}$ are known to be toxic to earthworms [24].

\subsection{Earthworm Addition, Experimental Conditions, and Sam-} ple Collection. At week 7, subsamples from all experimental units were removed for chemical analysis, and fifteen earthworms (Dendrobaena veneta) were added to one-half of 
TABLE 1: Elemental composition of mine tailings, biosolids, pulp sludge, and sawdust used in this experiment.

\begin{tabular}{|c|c|c|c|c|c|}
\hline Element & Units & Mine tailings & Biosolids & Pulp sludge & Sawdust \\
\hline $\mathrm{Si}$ & g $100 g^{-1}$ & 24.2 & ND & ND & ND \\
\hline $\mathrm{Al}$ & $\mathrm{g} 100 \mathrm{~g}^{-1}$ & 8.92 & 1.7 & 0.06 & 0.004 \\
\hline $\mathrm{Fe}$ & ${\mathrm{g} 100 \mathrm{~g}^{-1}}$ & 6.24 & 1.4 & 0.09 & 0.005 \\
\hline $\mathrm{Ca}$ & ${\mathrm{g} 100 \mathrm{~g}^{-1}}$ & 3.47 & 3.1 & 0.91 & 0.07 \\
\hline $\mathrm{Mg}$ & ${\mathrm{g} 100 \mathrm{~g}^{-1}}$ & 1.24 & 0.47 & 0.15 & 0.01 \\
\hline K & ${\mathrm{g} 100 \mathrm{~g}^{-1}}$ & 4.77 & 0.19 & 0.01 & 0.02 \\
\hline $\mathrm{Na}$ & $\mathrm{g} 100 \mathrm{~g}^{-1}$ & 2.97 & ND & ND & ND \\
\hline $\mathrm{Mn}$ & ${\mathrm{g} 100 \mathrm{~g}^{-1}}$ & 0.09 & 0.06 & 0.01 & 0.01 \\
\hline $\mathrm{C}$ & ${\mathrm{g} 100 \mathrm{~g}^{-1}}$ & 0.80 & 36.8 & 42.9 & 51.3 \\
\hline $\mathrm{N}$ & $\mathrm{g} 100 \mathrm{~g}^{-1}$ & 0.007 & 4.95 & 0.027 & 0.050 \\
\hline S & $\mathrm{g} 100 \mathrm{~g}^{-1}$ & 0.89 & 1.36 & 0.01 & $<0.01$ \\
\hline $\mathrm{P}$ & ${\mathrm{g} 100 \mathrm{~g}^{-1}}^{-1}$ & 0.17 & 2.31 & 0.01 & $<0.01$ \\
\hline As & $\mathrm{mg} \mathrm{kg}^{-1}$ & 20.9 & 5.2 & $<0.5$ & $<0.5$ \\
\hline $\mathrm{Cd}$ & $\mathrm{mg} \mathrm{kg}^{-1}$ & 0.53 & 2.8 & $<0.5$ & $<0.5$ \\
\hline Co & $\mathrm{mg} \mathrm{kg}^{-1}$ & 18.5 & 4.0 & $<2.0$ & $<2.0$ \\
\hline $\mathrm{Cr}$ & $\mathrm{mg} \mathrm{kg}^{-1}$ & 10 & 35 & 4 & $<2$ \\
\hline $\mathrm{Cu}$ & $\mathrm{mg} \mathrm{kg}^{-1}$ & 660 & 2.3 & 3.8 & 3.0 \\
\hline $\mathrm{Pb}$ & $\mathrm{mg} \mathrm{kg}^{-1}$ & 7 & 62 & $<30$ & $<30$ \\
\hline $\mathrm{Hg}$ & $\mathrm{mg} \mathrm{kg}^{-1}$ & 0.157 & 6.73 & 0.011 & 0.079 \\
\hline Mo & $\mathrm{mg} \mathrm{kg}^{-1}$ & 8 & 15 & $<4$ & $<4$ \\
\hline $\mathrm{Ni}$ & $\mathrm{mg} \mathrm{kg}^{-1}$ & 7 & 25 & $<5$ & $<5$ \\
\hline $\mathrm{Se}$ & $\mathrm{mg} \mathrm{kg}^{-1}$ & 3 & 10 & $<2$ & $<2$ \\
\hline $\mathrm{Zn}$ & $\mathrm{mg} \mathrm{kg}^{-1}$ & 8 & 790 & 8 & 8 \\
\hline
\end{tabular}

Concentrations are presented on an oven-dry equivalent (mass) basis.

ND: not determined.

$\mathrm{Hg}$ concentrations in biosolids from this facility are usually less than $1 \mathrm{mg} \mathrm{kg}^{-1}$.

TABle 2: Experimental treatments used in this study. Proportions ( $\mathrm{g}$ amendment $100 \mathrm{~g}^{-1}$ mine tailings) of organic amendments are presented on an equivalent oven-dry basis relative to initial mine tailings.

\begin{tabular}{|c|c|c|c|c|}
\hline \multirow[b]{2}{*}{ Biosolids } & \multirow[b]{2}{*}{ Sawdust } & \multirow[b]{2}{*}{ Pulp sludge } & \multicolumn{2}{|c|}{ Treatment code } \\
\hline & & & Without earthworms & With earthworms \\
\hline 10 & 10 & 0 & T1-WO & $\mathrm{T} 1-\mathrm{W}$ \\
\hline 10 & 0 & 10 & T2-WO & $\mathrm{T} 2-\mathrm{W}$ \\
\hline 10 & 5 & 5 & T3-WO & $\mathrm{T} 3-\mathrm{W}$ \\
\hline 10 & 0 & 0 & T4-WO & $\mathrm{T} 4-\mathrm{W}$ \\
\hline 20 & 10 & 0 & T5-WO & T5-W \\
\hline 20 & 0 & 10 & T6-WO & T6-W \\
\hline 20 & 5 & 5 & T7-WO & T7-W \\
\hline 20 & 0 & 0 & T8-WO & $\mathrm{T} 8-\mathrm{W}$ \\
\hline
\end{tabular}

Appropriate treatments received earthworms 7 weeks after the substrates were mixed and the incubation was started.

the treatments (Table 2). The incubation was conducted in a lighted room to discourage the escape of earthworms from the experimental units. Average $( \pm S D)$ live weight (with full guts) of the earthworms was $1.15 \pm 0.11 \mathrm{~g}$ per individual. Earthworms tunneled into the organic amended tailings immediately after addition except for treatments T4-W and T8-W where earthworms remained on the surface and died within a day of addition; treatments $\mathrm{T} 4-\mathrm{W}$ and $\mathrm{T} 8-\mathrm{W}$ were discontinued due to the immediate death of earthworms.
At week 13, the amended tailings from all experimental units were removed, placed into trays, and examined for earthworm survival. Subsamples of tailings were also removed for chemical analysis. Earthworms in treatment T5-W did not survive to week 13. Instead of discontinuing T5-W, fifteen new earthworms were added to the experimental units of this treatment at week 16.

Incubations were continued at $20^{\circ} \mathrm{C}$ for the duration of the experiment (week 29). Moisture loss was minimal and 
small water additions were only required every 2-3 weeks. Earthworm populations were counted and tailings samples were collected for chemical analyses and WHC measurements at the conclusion of the experiment. Samples were briefly stored at $4^{\circ} \mathrm{C}$ prior to chemical analyses.

2.4. Laboratory Analyses. Amended tailings were analyzed for selected physical and chemical properties. Water-holding capacity was determined by placing $300 \mathrm{~g}$ of tailings into a $500 \mathrm{~mL}$ plastic cylinder (bound with cheese cloth on the bottom) and tapping firmly three times in order to standardize packing. The tailings were then water-saturated from the bottom of the container. After $24 \mathrm{~h}$ of saturation, the tailings were allowed to drain freely for $10 \mathrm{~h}$ under conditions designed to minimize evaporation; free drainage had ceased at this time and subsamples were then removed for moisture content analysis. Gravimetric moisture content $\left(\mathrm{g} \mathrm{H}_{2} \mathrm{O}\right.$ $100 \mathrm{~g}^{-1}$ oven-dry (OD) tailings) was determined by drying tailings overnight at $105^{\circ} \mathrm{C}$. The $\mathrm{pH}$ was measured in $1: 4$ solids to deionized $\mathrm{H}_{2} \mathrm{O}(\mathrm{g}: \mathrm{mL})$ suspension [28]. Electrical conductivity of tailings was determined in saturated paste extracts using a conductivity meter [29]. Total C and $\mathrm{N}$ were determined on $<100$-mesh samples (air-dried, then ground in a ball mill) by dry combustion using an elemental analyzer [30]. Available $\mathrm{N}\left(\mathrm{NH}_{4}{ }^{+}-\mathrm{N}\right.$ and $\left.\mathrm{NO}_{3}{ }^{-}-\mathrm{N}\right)$ was determined by extraction with $2 \mathrm{M} \mathrm{KCl}$, followed by colorimetric $\mathrm{N}$ determination [26]. Potentially mineralizable $\mathrm{N}\left(\mathrm{NH}_{4}{ }^{+}-\mathrm{N}\right.$ plus $\mathrm{NO}_{3}{ }^{-}-\mathrm{N}$ ) was determined by 7-day anaerobic incubation at the end of the study [31]. Cation exchange capacity (CEC) and exchangeable $\mathrm{K}, \mathrm{Ca}, \mathrm{Mg}$, and $\mathrm{Na}$ were determined at pH 7.0 using the $\mathrm{NH}_{4} \mathrm{OAc}$ method [32]. Available $\mathrm{P}$ was determined on samples at the end of the incubation by the Bray 1 procedure [33].

2.5. Microstructural Analysis. After the laboratory analyses, we thought that additional spatial information about the soil structure would be useful to complement our observations. We made thin sections from two selected treatments (T2-WO and $\mathrm{T} 2-\mathrm{W}$ ) to qualitatively describe the changes in soil microstructure due to organic and earthworm amendments. Thin sections were prepared by impregnating the sample with epoxy resin and subsequent grinding and polishing using corundum to a $30 \mu \mathrm{m}$ soil section. We described the sections under a Nikon Eclipse E600 polarizing microscope at the University of Northern British Columbia (Prince George, Canada) for micromorphological characteristics following the concepts and terminology in [34].

2.6. Statistical Analysis. The observed parameters were analyzed using a 1-way ANOVA in Statistica, v 6 [35]. Differences between treatments were determined by Student Newman Keuls (SNK) test. Earthworm numbers were transformed $(\log 10)$ prior to statistical analysis.

\section{Results}

3.1. Chemical Properties of Amended Mine Tailings at Beginning of Incubation. Subsamples obtained $24 \mathrm{~h}$ following the mixing of substrates showed the relatively neutral $\mathrm{pH}$ and moderate electrical conductivity in the experimental treatments (Table 3). Nitrate- $\mathrm{N}$ concentrations were low, but $\mathrm{NH}_{4}{ }^{+}-\mathrm{N}$ concentrations were very high with treatment averages ranging from 254 to $654 \mathrm{mg} \mathrm{N} \mathrm{kg}^{-1}$. Treatments receiving $20 \%$ biosolids had significantly greater $\mathrm{NH}_{4}{ }^{+}-\mathrm{N}$ and total $\mathrm{N}$ than treatments receiving $10 \%$ biosolids.

3.2. Dynamics of Nitrogen in Response to Amendment Additions. Within each of the two biosolid addition rates, the concentration of $\mathrm{NH}_{4}{ }^{+}-\mathrm{N}$ at week 7 was lowest in treatments T2-WO (Figure 1(a)) and T6-WO (Figure 1(b)), the two treatments that also received $10 \%$ pulp sludge. In contrast, treatments T4-WO (Figure 1(a)) and T7-WO (Figure 1(b)), the two biosolids-only treatments, had very high $\mathrm{NH}_{4}{ }^{+}-\mathrm{N}$ concentrations at week 7 . By week 13 , all treatments had very low $\mathrm{NH}_{4}{ }^{+}-\mathrm{N}$ concentrations, except for the two biosolidsonly treatments.

Concentrations of $\mathrm{NO}_{3}{ }^{-}-\mathrm{N}$ increased over the experiment in most treatments, but did not show any significant earthworm effects (Figures 2(a) and 2(b)). By week 13, $\mathrm{NO}_{3}{ }^{-}-\mathrm{N}$ concentrations were generally much greater in treatments receiving $20 \%$ biosolids than those treatments receiving $10 \%$ biosolids.

For each of the two biosolid addition rates, the decline in $\mathrm{C} / \mathrm{N}$ ratio for amended tailings was more extensive and more rapid for treatments also receiving 10\% pulp sludge (Figures $3(\mathrm{a})$ and $3(\mathrm{~b}))$. The presence of earthworms did not have a significant effect on $\mathrm{C} / \mathrm{N}$ ratios. Treatments receiving 20\% biosolids generally had lower $\mathrm{C} / \mathrm{N}$ ratios than treatments receiving $10 \%$ biosolids.

3.3. Selected Properties of Amended Mine Tailings at End of Study. Comparison of treatment effects on nitrogen parameters showed that the presence of earthworms did not significantly influence $\mathrm{C} / \mathrm{N}$ ratio, $\mathrm{NH}_{4}{ }^{+}-\mathrm{N}$, or potentially mineralizable $\mathrm{N}$ at the end of the study (Table 4). Although $\mathrm{NO}_{3}{ }^{-}-\mathrm{N}$ concentrations tended to be greater for an amendment treatment when earthworms were present, these differences were usually not statistically significant (Table 4). Potentially mineralizable $\mathrm{N}$, total $\mathrm{N}$, and $\mathrm{NO}_{3}{ }^{-}-\mathrm{N}$ concentrations were generally greater in treatments receiving $20 \%$ biosolids as compared to treatments receiving 10\% biosolids.

Earthworms did not have significant effects on $\mathrm{pH}$, WHC, or CEC (Table 5). Although average values for EC tended to be greater for amendment treatments when earthworms were present, these differences were not statistically significant. The two biosolids-only treatments (T4-WO and T8-WO) had the greatest EC values measured in the study. Values of CEC were generally greater in treatments receiving $20 \%$ biosolids as compared to those receiving $10 \%$ biosolids. There was a positive correlation between $\mathrm{NO}_{3}{ }^{-}-\mathrm{N}$ concentrations and EC at the end of the study $(r=0.773, P<$ $0.0001)$, as well as throughout the experiment $(r=0.833$, $P<0.0001)$.

The presence of earthworms was associated with higher Bray $\mathrm{P}$ concentrations within amendment treatments by the end of the study. Average Bray $\mathrm{P}$ was significantly greater 
TABLE 3: Selected chemical properties of amended mine tailings sampled 24 hours after experimental setup. Means \pm standard deviation $(n=3)$. Values designated by the same letter (within a column) are not significantly different from each other $(P<0.05)$.

\begin{tabular}{|c|c|c|c|c|c|}
\hline Treatment & $\mathrm{pH}$ (water) & $\mathrm{EC}\left(\mathrm{dS} \mathrm{m}^{-1}\right)$ & $\mathrm{NH}_{4}^{+}-\mathrm{N}\left(\mathrm{mg} \mathrm{kg}^{-1}\right)$ & $\mathrm{NO}_{3}{ }^{-}-\mathrm{N}\left(\mathrm{mg} \mathrm{kg}^{-1}\right)$ & Total N $\left({\left.\mathrm{g} 100 \mathrm{~g}^{-1}\right)}^{2}\right.$ \\
\hline \multicolumn{6}{|c|}{ Treatments with $10 \%$ biosolids } \\
\hline T1-WO & $7.37 \pm 0.03 c$ & $3.19 \pm 0.05 \mathrm{~d}$ & $345 \pm 20 c$ & $0.3 \pm 0.1 \mathrm{a}$ & $0.34 \pm 0.03 b$ \\
\hline T2-WO & $7.72 \pm 0.06 a$ & $2.34 \pm 0.04 \mathrm{e}$ & $254 \pm 9 d$ & $0.3 \pm 0.1 \mathrm{a}$ & $0.30 \pm 0.04 b$ \\
\hline T3-WO & $7.35 \pm 0.01 c$ & $3.16 \pm 0.06 \mathrm{~d}$ & $261 \pm 70 d$ & $1.9 \pm 0.2 \mathrm{a}$ & $0.30 \pm 0.09 b$ \\
\hline T4-WO & $7.43 \pm 0.02 \mathrm{bc}$ & $5.29 \pm 0.12 b$ & $387 \pm 19 \mathrm{c}$ & $0.1 \pm 0.1 \mathrm{a}$ & $0.35 \pm 0.01 b$ \\
\hline \multicolumn{6}{|c|}{ Treatments with $20 \%$ biosolids } \\
\hline T5-WO & $7.24 \pm 0.06 \mathrm{~d}$ & $4.69 \pm 0.09 c$ & $615 \pm 10 \mathrm{a}$ & $0.2 \pm 0.03 a$ & $0.60 \pm 0.02 \mathrm{a}$ \\
\hline T6-WO & $7.45 \pm 0.03 b$ & $3.50 \pm 0.06 \mathrm{~d}$ & $491 \pm 25 b$ & $1.3 \pm 0.1 \mathrm{a}$ & $0.57 \pm 0.04 \mathrm{a}$ \\
\hline T7-WO & $7.26 \pm 0.02 \mathrm{~d}$ & $4.44 \pm 0.27 \mathrm{c}$ & $524 \pm 31 b$ & $0.9 \pm 0.3 \mathrm{a}$ & $0.64 \pm 0.06 a$ \\
\hline T8-WO & $7.27 \pm 0.05 \mathrm{~d}$ & $6.34 \pm 0.06 a$ & $654 \pm 26 a$ & $0.3 \pm 0.3 \mathrm{a}$ & $0.60 \pm 0.07 \mathrm{a}$ \\
\hline
\end{tabular}

Concentrations are expressed on an oven-dry equivalent basis.

For reference, $\mathrm{pH}$ and EC of pure mine tailings were $8.31 \pm 0.05$ and $1.80 \pm 0.04 \mathrm{dS} \mathrm{m}^{-1}$, respectively $(n=3)$.

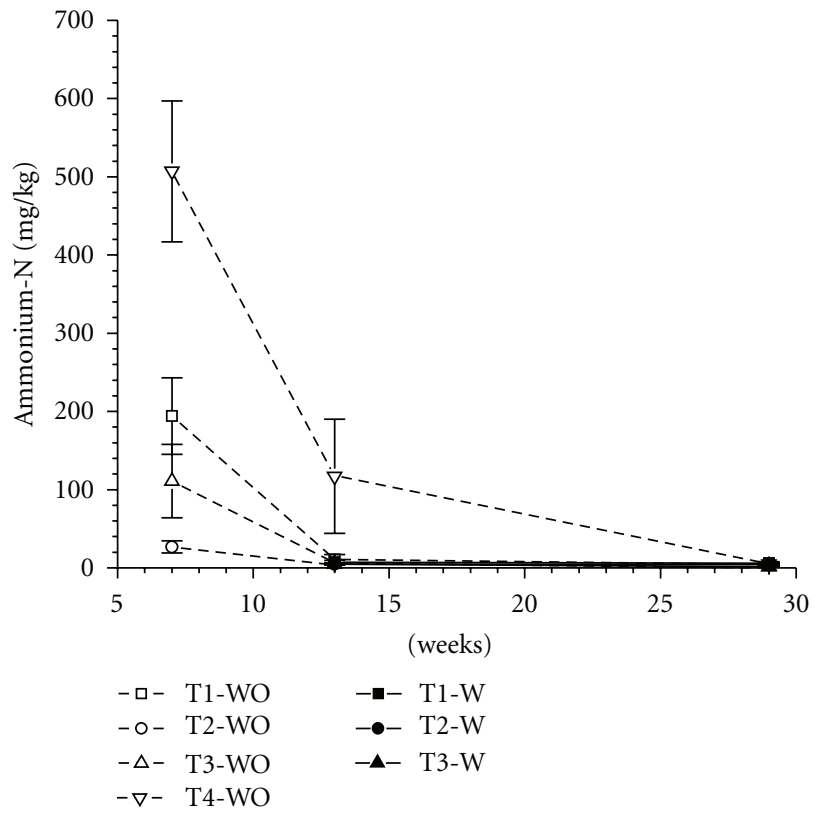

(a)

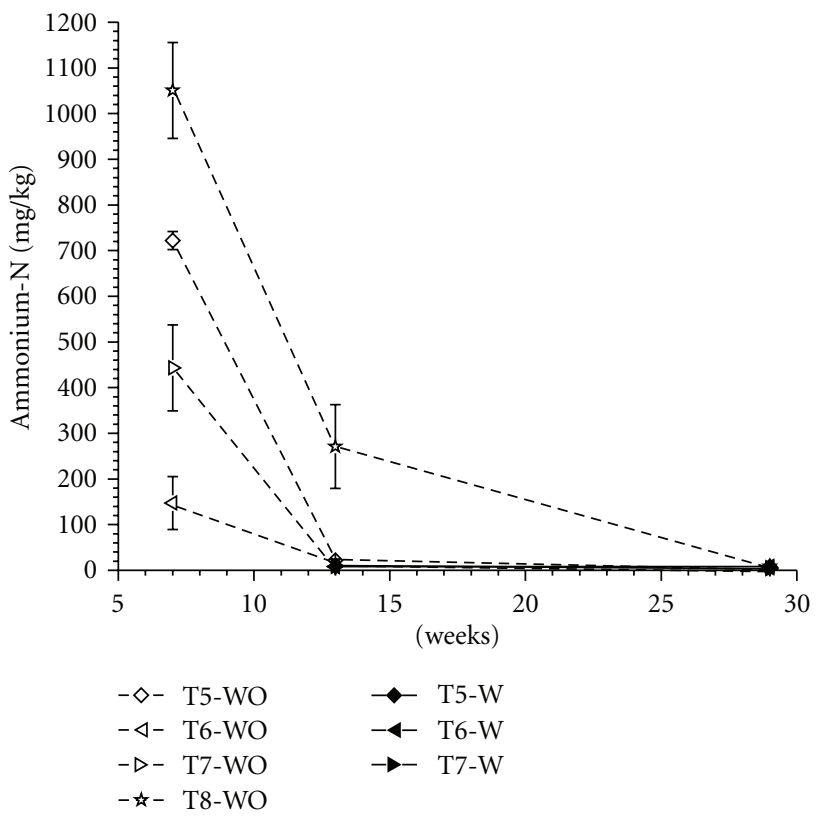

(b)

FIGURE 1: Mean $\mathrm{NH}_{4}{ }^{+}-\mathrm{N}$ concentrations in amended mine tailings; (a) treatments that included 10\% biosolids addition; (b) treatments that included $20 \%$ biosolids addition. Error bars indicate $( \pm 1$ SD; $n=3)$. See Table 2 for explanation of treatment codes.

in several amendment mixtures when earthworms where present as compared to when they were absent (Table 5).

3.4. Earthworm Populations and Other Observations. Earthworms in treatments that received pulp sludge (T2-W, T3$\mathrm{W}, \mathrm{T} 6-\mathrm{W}$, and $\mathrm{T} 7-\mathrm{W}$ ) were large and very active throughout most of the study. Earthworm activity in these treatments was very apparent by week 13, with young earthworms being present in experimental units with larger earthworms. Abundant fungal growth was clearly visible at week 7 , the time of earthworm addition, in treatments that received pulp sludge. In general, by the end of the study earthworms were smaller and less active than those observed at week 13. Earthworm numbers at the end of the study tended to be greater in treatments that included pulp sludge (T2-W, T3-W, T6-W, and T7-W) and least in treatments that only received biosolids and sawdust (T1-W and T7-W; Table 6).

Treatments with earthworms often exhibited small tunnels within the tailings at the bottom of the experimental units, and mineral surfaces exhibited shinier surfaces relative to treatments without earthworms; this was more apparent in pulp sludge-amended treatments. Although not measured in this study, the addition of pulp sludge appeared to aggregate the tailings more than those receiving sawdust. The "aggregates" observed in this study included true aggregates 


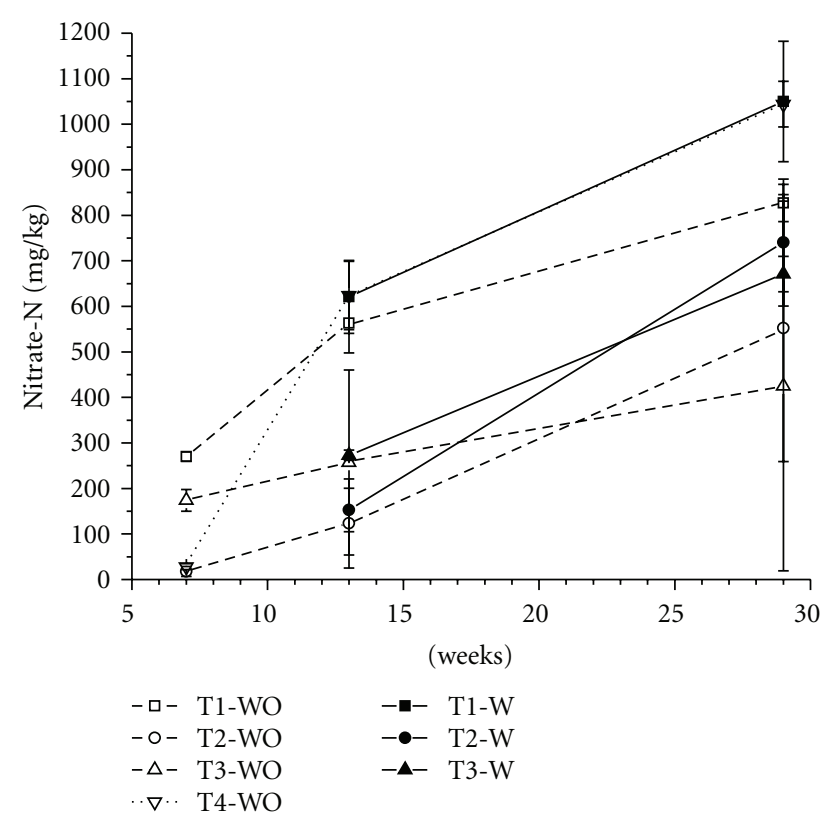

(a)

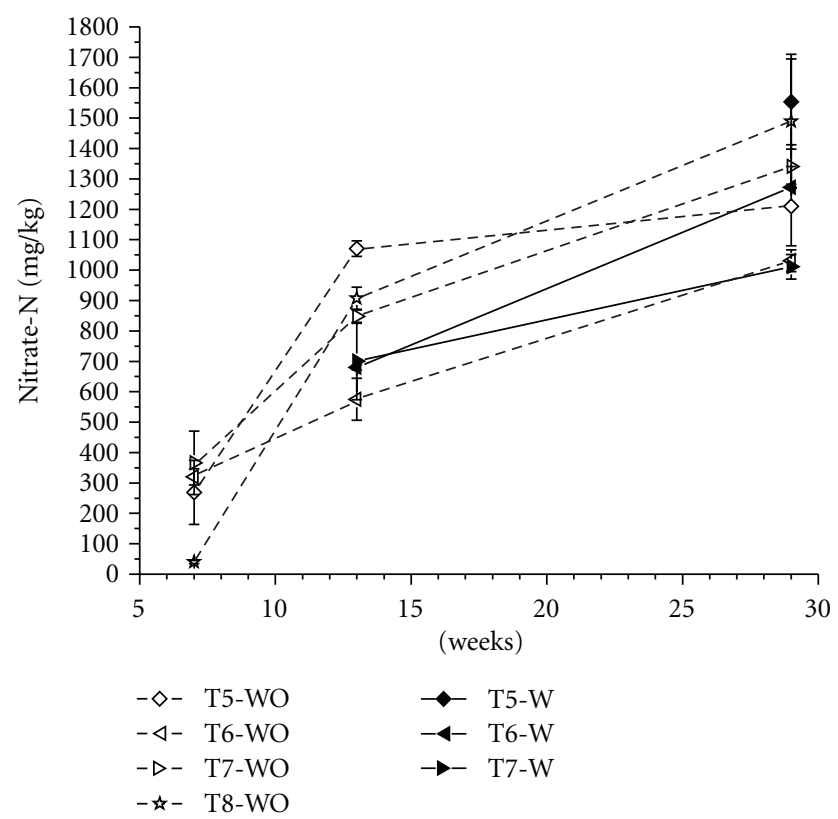

(b)

Figure 2: Mean $\mathrm{NO}_{3}{ }^{-}-\mathrm{N}$ concentrations in amended mine tailings; (a) treatments that included $10 \%$ biosolids addition; (b) treatments that included $20 \%$ biosolids addition. Error bars indicate $( \pm 1 \mathrm{SD}$; $n=3)$. See Table 2 for explanation of treatment codes.

(i.e., primary particles aggregated weakly into secondary aggregates) and also residual biosolid particles and other residual organic debris (e.g., wood sawdust) from the organic amendments.

3.5. Soil Microstructure. By week 29, organic residues added to the mine tailings were still recognizable in soil thin sections (Figure 4). These residues were intimately mixed with

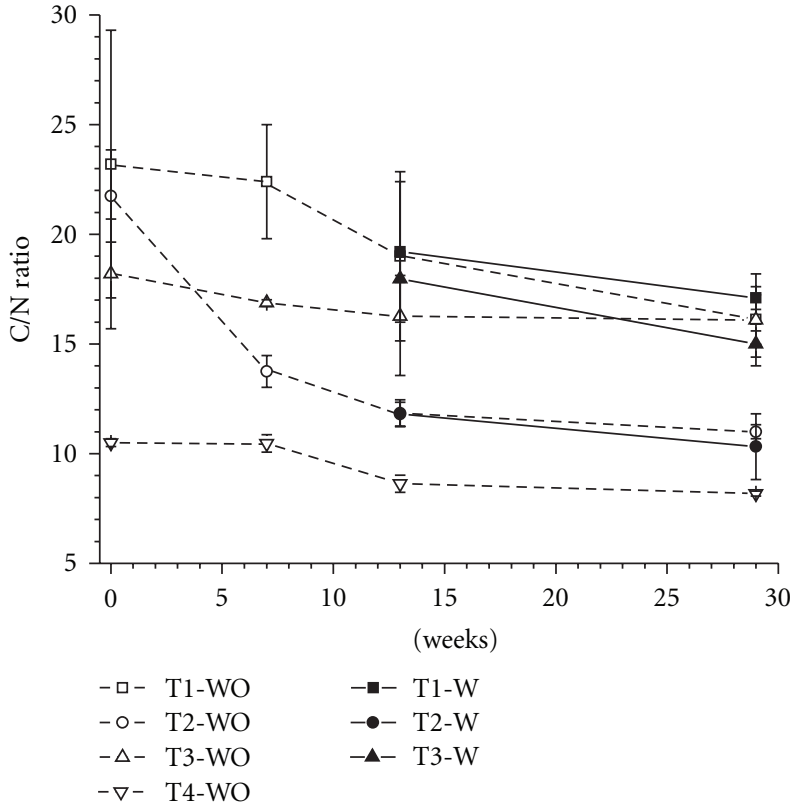

(a)

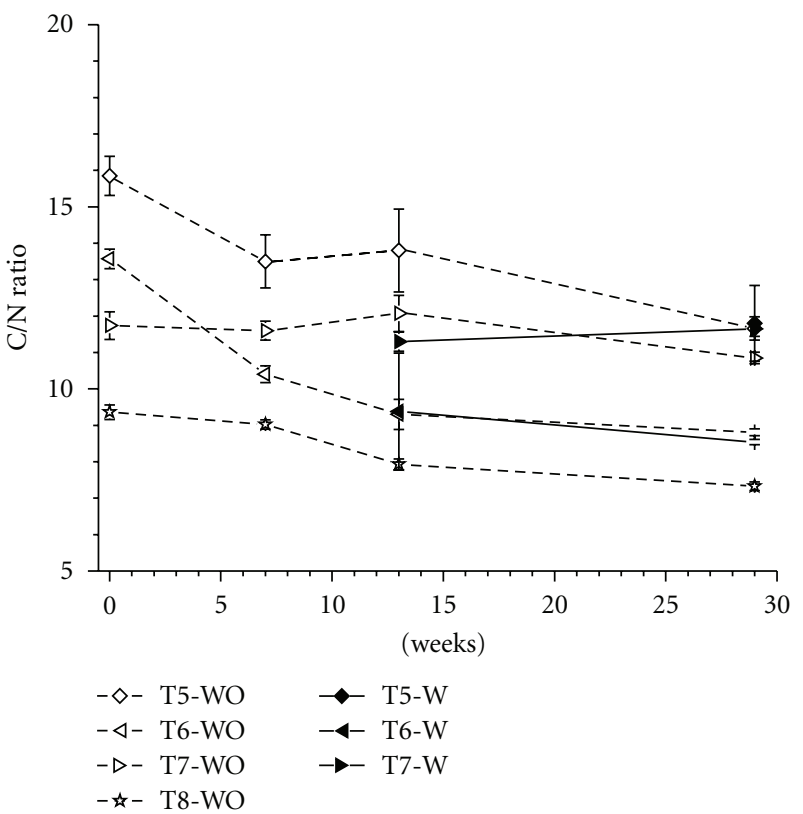

(b)

FIGURE 3: Mean C/N ratio of amended mine tailings; (a) treatments that included $10 \%$ biosolids addition; (b) treatments that included $20 \%$ biosolids addition. Error bars indicate $( \pm 1$ SD; $n=3)$. See Table 2 for explanation of treatment codes.

the inorganic materials in T2-W (with earthworms) (Figures $4(\mathrm{a})$ and $4(\mathrm{~b})$ ) while discrete residues were present in isolated patches in T2-WO (without earthworms; Figures 4(c) and $4(\mathrm{~d}))$. The contiguous discrete rounded microfabric units in T2-W formed an outline of elongated $(\sim 8 \mathrm{~mm} \times$ $4 \mathrm{~mm}$ ) spherical units composed of organic and mineral materials (Figure 4(a)). The discrete units of residues in T2-WO exhibited a cracked pattern (Figure $4(\mathrm{~d})$ ) not observed in 
TABle 4: Mean ( \pm standard deviation) C/N ratio, ammonium-N, nitrate-N, potentially mineralizable $\mathrm{N}$ (7-day anaerobic incubation), and total nitrogen at the end of the study (week 29). Values designated by same letter (within a column) are not significantly different from each other by SNK $(P<0.05 ; n=3)$.

\begin{tabular}{lccccc}
\hline Treatment & C/N ratio & $\mathrm{NH}_{4}{ }^{-}-\mathrm{N}\left(\mathrm{mg} \mathrm{kg}^{-1}\right)$ & $\mathrm{NO}_{3}^{-}-\mathrm{N}\left(\mathrm{mg} \mathrm{kg}^{-1}\right)$ & Mineralizable-N $\left(\mathrm{mg} \mathrm{kg}^{-1}\right)$ & ${\mathrm{Total} \mathrm{N}\left(\mathrm{g} 100 \mathrm{~g}^{-1}\right)}$ \\
\hline T1-WO & $16.1 \pm 1.1 \mathrm{ab}$ & $4.3 \pm 0.7 \mathrm{~d}$ & Treatments with $10 \%$ biosolids & \\
T1-W & $17.1 \pm 0.5 \mathrm{a}$ & $6.0 \pm 1.9 \mathrm{bcd}$ & $1050 \pm 132 \mathrm{bcd}$ & $31.2 \pm 16.8 \mathrm{cde}$ & $0.39 \pm 0.04 \mathrm{c}$ \\
T2-WO & $11.0 \pm 0.3 \mathrm{c}$ & $4.1 \pm 0.1 \mathrm{~d}$ & $553 \pm 293 \mathrm{ef}$ & $73.9 \pm 5.6 \mathrm{cde}$ & $0.35 \pm 0.02 \mathrm{~cd}$ \\
T2-W & $10.3 \pm 0.4 \mathrm{c}$ & $4.3 \pm 1.5 \mathrm{~d}$ & $740 \pm 139 \mathrm{de}$ & $51.0 \pm 14.6 \mathrm{de}$ & $0.36 \pm 0.03 \mathrm{~cd}$ \\
T3-WO & $16.1 \pm 2.1 \mathrm{ab}$ & $1.9 \pm 0.2 \mathrm{e}$ & $425 \pm 406 \mathrm{f}$ & $65.4 \pm 14.1 \mathrm{cde}$ & $0.34 \pm 0.01 \mathrm{~cd}$ \\
T3-W & $15.0 \pm 0.6 \mathrm{~b}$ & $1.7 \pm 0.2 \mathrm{e}$ & $672 \pm 39 \mathrm{de}$ & $30.4 \pm 7.9 \mathrm{e}$ & $0.31 \pm 0.02 \mathrm{~cd}$ \\
T4-WO & $8.2 \pm 0.1 \mathrm{~d}$ & $4.9 \pm 0.6 \mathrm{~d}$ & $1043 \pm 50 \mathrm{bcd}$ & $102.9 \pm 10.3 \mathrm{bcd}$ & $0.30 \pm 0.01 \mathrm{~d}$ \\
\hline & & & & $0.39 \pm 0.02 \mathrm{c}$ \\
T5-WO & $11.7 \pm 0.3 \mathrm{c}$ & $6.9 \pm 0.8 \mathrm{abc}$ & $1210 \pm 131 \mathrm{abc}$ & $153.6 \pm 48.6 \mathrm{ab}$ & $0.64 \pm 0.09 \mathrm{ab}$ \\
T5-W & $11.8 \pm 1.0 \mathrm{c}$ & $7.9 \pm 0.8 \mathrm{ab}$ & $1554 \pm 156 \mathrm{a}$ & $184.3 \pm 23.3 \mathrm{a}$ & $0.69 \pm 0.05 \mathrm{a}$ \\
T6-WO & $8.8 \pm 0.1 \mathrm{~d}$ & $5.3 \pm 0.9 \mathrm{~cd}$ & $1031 \pm 36 \mathrm{bcd}$ & $141.7 \pm 41.8 \mathrm{ab}$ & $0.59 \pm 0.03 \mathrm{~b}$ \\
T6-W & $8.5 \pm 0.1 \mathrm{~d}$ & $8.0 \pm 0.5 \mathrm{a}$ & $1272 \pm 40 \mathrm{ab}$ & $199.6 \pm 33.9 \mathrm{a}$ & $0.69 \pm 0.05 \mathrm{a}$ \\
T7-WO & $10.8 \pm 0.2 \mathrm{c}$ & $4.5 \pm 0.2 \mathrm{~d}$ & $1341 \pm 72 \mathrm{ab}$ & $144.7 \pm 25.7 \mathrm{ab}$ & $0.61 \pm 0.004 \mathrm{ab}$ \\
T7-W & $11.7 \pm 0.2 \mathrm{c}$ & $3.7 \pm 0.6 \mathrm{~d}$ & $1011 \pm 40 \mathrm{bcd}$ & $112.4 \pm 9.8 \mathrm{bc}$ & $0.58 \pm 0.02 \mathrm{~b}$ \\
T8-WO & $7.3 \pm 0.1 \mathrm{~d}$ & $8.4 \pm 1.1 \mathrm{a}$ & $1490 \pm 206 \mathrm{a}$ & $157.5 \pm 22.0 \mathrm{ab}$ & $0.63 \pm 0.01 \mathrm{ab}$ \\
\hline
\end{tabular}

Concentrations are expressed on an oven-dry (mass) equivalent basis.

See Table 2 for explanation of treatments.

TABLE 5: Mean ( \pm standard deviation) pH, electrical conductivity, Bray extractable phosphorus, cation exchange capacity, and water holdingcapacity at the end of the study (week 29). Values designated by same letter (within a column) are not significantly different from each other $(P<0.05 ; n=3)$.

\begin{tabular}{|c|c|c|c|c|c|}
\hline Treatment & $\mathrm{pH}$ & $\mathrm{EC}\left(\mathrm{dS} \mathrm{m}^{-1}\right)$ & Bray P (mg P kg-1) & $\mathrm{CEC}\left(\mathrm{cmol}_{\mathrm{c}} \mathrm{kg}^{-1}\right)$ & WHC $\left(\mathrm{g} \mathrm{H}_{2} \mathrm{O} 100 \mathrm{~g}^{-1}\right)$ \\
\hline \multicolumn{6}{|c|}{ Treatments with $10 \%$ biosolids } \\
\hline T1-WO & $6.77 \pm 0.01 \mathrm{bcd}$ & $9.00 \pm 0.38 \mathrm{de}$ & $237 \pm 20 \mathrm{~cd}$ & $5.81 \pm 0.48 \mathrm{ef}$ & $68.8 \pm 3.6 \mathrm{abc}$ \\
\hline T1-W & $6.64 \pm 0.07 \mathrm{de}$ & $10.04 \pm 0.63 \mathrm{de}$ & $324 \pm 123 \mathrm{bc}$ & $7.32 \pm 0.60 \mathrm{cdef}$ & $66.3 \pm 3.1 \mathrm{bcd}$ \\
\hline T2-WO & $6.91 \pm 0.03 b c$ & $7.58 \pm 0.58 \mathrm{ef}$ & $195 \pm 57 c d$ & $5.32 \pm 0.66 f$ & $54.1 \pm 7.8 \mathrm{~d}$ \\
\hline $\mathrm{T} 2-\mathrm{W}$ & $6.66 \pm 0.05$ cde & $10.01 \pm 1.30 \mathrm{de}$ & $487 \pm 63 a$ & $7.26 \pm 0.38 \mathrm{cdef}$ & $58.6 \pm 1.4 \mathrm{~cd}$ \\
\hline T3-WO & $7.27 \pm 0.31 \mathrm{a}$ & $5.65 \pm 2.70 \mathrm{f}$ & $224 \pm 16 \mathrm{~cd}$ & $7.68 \pm 0.44 \mathrm{cdef}$ & $64.1 \pm 5.6 \mathrm{bcd}$ \\
\hline T3-W & $6.83 \pm 0.04 \mathrm{bcd}$ & $7.76 \pm 0.40 \mathrm{ef}$ & $482 \pm 78 \mathrm{a}$ & $6.19 \pm 0.51 \mathrm{def}$ & $68.7 \pm 6.3 \mathrm{abc}$ \\
\hline T4-WO & $6.97 \pm 0.01 \mathrm{~b}$ & $16.0 \pm 0.25 \mathrm{a}$ & $117 \pm 24 \mathrm{~d}$ & $4.87 \pm 1.26 f$ & $40.0 \pm 1.6 \mathrm{e}$ \\
\hline \multicolumn{6}{|c|}{ Treatments with $20 \%$ biosolids } \\
\hline T5- WO & $6.72 \pm 0.12 \mathrm{~cd}$ & $11.37 \pm 0.83 \mathrm{cde}$ & $270 \pm 22 b c$ & $9.77 \pm 0.48 \mathrm{abc}$ & $81.9 \pm 3.4 \mathrm{a}$ \\
\hline T5-W & $6.57 \pm 0.02 \mathrm{def}$ & $12.51 \pm 1.45 \mathrm{~cd}$ & $349 \pm 23 \mathrm{abc}$ & $10.36 \pm 0.53 \mathrm{abc}$ & $77.7 \pm 10.2 \mathrm{ab}$ \\
\hline T6-WO & $6.46 \pm 0.02 \mathrm{ef}$ & $11.24 \pm 3.65 \mathrm{cde}$ & $296 \pm 22 b c$ & $8.46 \pm 0.68 \mathrm{bcde}$ & $64.7 \pm 3.0 \mathrm{bcd}$ \\
\hline T6-W & $6.36 \pm 0.06 f$ & $13.89 \pm 0.60 \mathrm{bc}$ & $393 \pm 12 \mathrm{ab}$ & $8.74 \pm 2.16 \mathrm{bcd}$ & $74.3 \pm 2.7 \mathrm{ab}$ \\
\hline T7-WO & $6.63 \pm 0.04 \mathrm{cde}$ & $12.50 \pm 0.91 \mathrm{~cd}$ & $257 \pm 12 \mathrm{bc}$ & $11.63 \pm 0.97 \mathrm{a}$ & $70.0 \pm 6.6 \mathrm{abc}$ \\
\hline T7-W & $6.90 \pm 0.10 \mathrm{bc}$ & $9.88 \pm 0.37 \mathrm{de}$ & $463 \pm 118 \mathrm{a}$ & $11.21 \pm 1.35 \mathrm{ab}$ & $73.9 \pm 4.9 \mathrm{ab}$ \\
\hline T8-WO & $6.63 \pm 0.03 \mathrm{cde}$ & $20.1 \pm 0.94 \mathrm{a}$ & $271 \pm 11 b c$ & $10.6 \pm 2.22 \mathrm{ab}$ & $55.6 \pm 4.9 \mathrm{~d}$ \\
\hline
\end{tabular}

Bray P, CEC, and WHC are expressed relative to oven-dry (mass) tailings.

rounded microfabric units (Figure 4(b)). Accumulations of near pure organic matter normally exhibit a cracked pattern upon desiccation [36]. In a typical microfabric in T2-WO, a large section (i.e., upper 75\% in Figure 4(a)) is composed of mixed organic matter and mine tailings. This contrasts with $\mathrm{T} 2-\mathrm{WO}$ where the microfabric is composed mainly of mine tailings, with isolated patches of discrete residues (Figure $4(c))$.

\section{Discussion}

The mine tailings in this study consisted mainly of feldspar mineral particles of a very fine sand texture. Concentrations of trace elements were generally low, with the exception of copper $\left(660 \mathrm{mg} \mathrm{kg}^{-1}\right)$. For comparison, the Canadian Soil Quality Guidelines for copper in agricultural and industrial soils are 63 and $91 \mathrm{mg} \mathrm{kg}^{-1}$, respectively [37]. The biosolids 


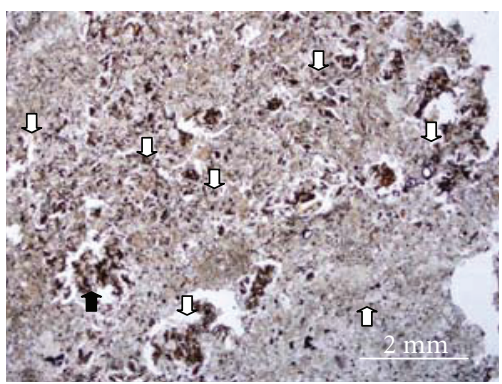

(a)

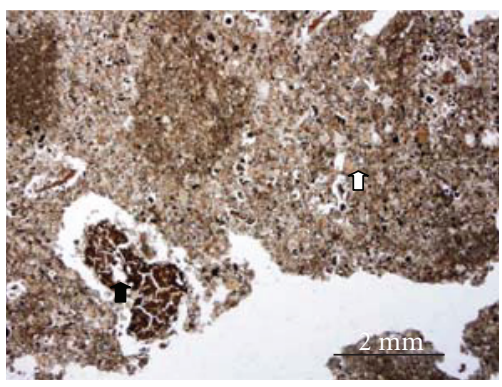

(c)

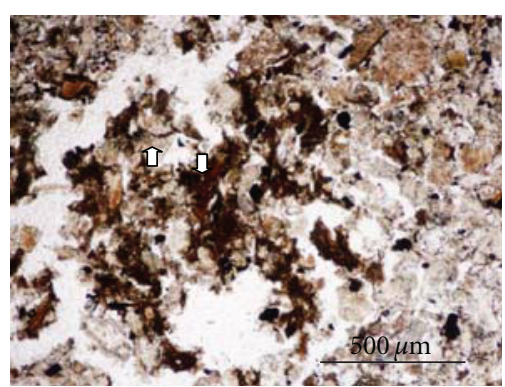

(b)

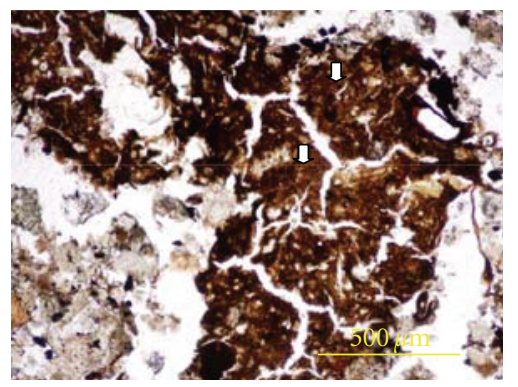

(d)

FIGURE 4: Microfabric of mine tailings amended with organic residues with or without earthworms. After 29 weeks, the organic residues (white down arrow) were intimately mixed in (a) T2-W (10\% biosolids, $10 \%$ pulp sludge, with earthworms), compared to (c) discrete unit showing cracked pattern in T2-WO (10\% biosolids, 10\% pulp sludge, without earthworms). Close-up images of sections marked by (black up arrow) in (a) and (c) show the (b) intimate mixing of organic residues (white down arrow) with inorganic materials (white up arrow) and (d) the cracked pattern of organic residues (white down arrow) not mixed with inorganic materials.

TABLE 6: Mean earthworm numbers ( \pm standard deviation) in each of the experimental units at the end of the study $(n=3)$.

\begin{tabular}{lc}
\hline Treatment & Earthworm numbers \\
\hline T1-W & $7.0 \pm 3.6 \mathrm{ab}$ \\
T2-W & $19.7 \pm 17.6 \mathrm{a}$ \\
T3-W & $12.7 \pm 0.6 \mathrm{ab}$ \\
T5-W & $2.0 \pm 2.8 \mathrm{~b}$ \\
T6-W & $20.3 \pm 10.4 \mathrm{a}$ \\
T7-W & $11.7 \pm 3.2 \mathrm{ab}$ \\
\hline
\end{tabular}

Treatments T4-W and T8-W were discontinued at week 7 when earthworms died immediately after addition.

amendments are increasingly being used in the reclamation of mine soils mainly to improve plant nutrient levels and to improve soil chemical and physical properties [10]. In this study, we show that coapplication of other organic substrates can enhance soil properties compared to the addition of biosolids alone. The epigeic earthworm Dendobaena veneta only survived in biosolids-amended mine tailings when other organic substrates were coapplied. Pulp sludge addition appeared to be more beneficial to earthworms than softwood sawdust.

4.1. Effect of Immobilizer Substrates on Soil Properties. Very low concentrations of $\mathrm{N}$ and $\mathrm{P}$ (e.g., $<0.01 \%$ and $<0.20 \%$, resp., in this study) are often the most limiting characteristics to plant growth in nonacidic mine tailings. The current study is consistent with other research that shows addition of bio- solids improves total $\mathrm{N}$ content of mine residuals such as tailings [38]. Although total $\mathrm{N}$ concentrations after 29 weeks of organic residue addition were $<0.7 \%$, these concentrations are typical of temperate cultivated soils [30] and are also comparable to soil organic $\mathrm{N}$ accumulation in pioneer species in acidic mine tailings in southeast Spain [15]. This increase in total $\mathrm{N}$ coupled with more available $\mathrm{P}$ in organic and earthworm amended tailings may be sufficient to initiate soil formation and promote plant growth in nonacidic mine tailings. In the Czech Republic, Frouz and Nováková [39] argued that soil formation and organic matter accumulation is crucial to the restoration of ecosystem functions in postmining landscape.

In addition to further improving soil physical properties, the use of "immobilizer" substrates can be used to manipulate nitrogen originating from $\mathrm{N}$-rich substrates. Chaves et al. [40] define immobilizer substrates as those which have net $\mathrm{N}$ immobilization potential. Biosolids used in this study initially had a low $\mathrm{C} / \mathrm{N}$ ratio (7.4) and very high $\mathrm{NH}_{4}{ }^{+}-\mathrm{N}$ concentrations ( $2490 \mathrm{mg} \mathrm{NH}_{4}{ }^{+}-\mathrm{N} \mathrm{kg}^{-1}$ ). High $\mathrm{NH}_{4}{ }^{+}-\mathrm{N}$ concentrations may lead to excessive $\mathrm{N}$ losses in field soils through volatilization $\left(\mathrm{NH}_{3}\right)$ or as $\mathrm{NO}_{3}{ }^{-}$-N leaching following nitrification [41]. High $\mathrm{NH}_{4}{ }^{+} / \mathrm{NH}_{3}$ concentrations are also toxic to some soil invertebrates such as earthworms [24] and young plants. Immobilizer substrates can temporarily immobilize mineral $\mathrm{N}\left(\mathrm{NH}_{4}{ }^{+}-\mathrm{N}\right.$ or $\left.\mathrm{NO}_{3}{ }^{-}-\mathrm{N}\right)$ into organic matter (e.g., microbial biomass) which then gradually remineralize the nitrogen over time, ideally in synchrony with plant demand [40]. 
In this study, pulp sludge was a more effective immobilizer substrate than wood shavings. At 7 weeks, the mineral $\mathrm{N}\left(\mathrm{NH}_{4}{ }^{+}-\mathrm{N}+\mathrm{NO}_{3}{ }^{-}-\mathrm{N}\right)$ concentration in the $10 \%$ biosolids : $10 \%$ pulp sludge treatment (T2-WO) was only $45 \mathrm{mg}$ $\mathrm{N} \mathrm{kg}^{-1}$ soil, compared to $464 \mathrm{mg} \mathrm{N} \mathrm{kg}^{-1}$ in the $10 \%$ biosolids : $10 \%$ wood shavings (T1-WO). For comparison, the $10 \%$ biosolids-only treatment (T4-WO) had a mineral $\mathrm{N}$ concentration of $535 \mathrm{mg} \mathrm{N} \mathrm{kg}$. The more rapid and extensive drop in $\mathrm{C} / \mathrm{N}$ ratio in $\mathrm{T} 2-\mathrm{WO}$ compared to $\mathrm{T} 1-\mathrm{WO}$ over the first 7 weeks is consistent with greater microbial activity (and loss of $\mathrm{C}$ as respired $\mathrm{CO}_{2}-\mathrm{C}$ ) in the pulp sludge amended tailings compared to the sawdust-amended tailings (Figure 3(a)). Total carbon concentration decreased by $28 \%$ in the T2-WO treatment over the first 7 weeks, while the change in the T1-WO treatment was negligible (data not shown). Results for mineral N and $\mathrm{C} / \mathrm{N}$ for the $20 \%$ biosolids treatments at 7 weeks followed the same trends but pulp sludge concentrations were not great enough to reduce mineral $\mathrm{N}$ concentrations to the same extent as in the $10 \%$ biosolids treatments (Figure 3(b)). The very high concentrations of $\mathrm{NH}_{4}^{+}-\mathrm{N}$ in the $10 \%$ biosolids-only treatment (T4-WO; $507 \mathrm{mg} \mathrm{N} \mathrm{kg}^{-1}$ ), 20\% biosolids-only treatment (T8-WO; $1051 \mathrm{mg} \mathrm{N} \mathrm{kg}^{-1}$ ), and the $20 \%$ biosolids: $10 \%$ sawdust treatment (T5-WO; $721 \mathrm{mg} \mathrm{N} \mathrm{kg}{ }^{-1}$ ) at 7 weeks likely contributed to the death of the earthworms that were added at that time [24]. Similar $\mathrm{NH}_{4}{ }^{+}-\mathrm{N}_{\text {and }} \mathrm{NO}_{3}{ }^{-}-\mathrm{N}$ concentrations, and potentially mineralizable $\mathrm{N}$, at the end of the study (within a biosolids application rate) suggest that all organic matter amendments had similar effects on available $\mathrm{N}$ over the longer term.

The decrease in $\mathrm{pH}$ observed in this study supports earlier literature that soils receiving organic substrates, due largely to formation of carbonic and other acids during decomposition processes and increased nitrification, increases the acidity of the artificial soils. The slight decrease in $\mathrm{pH}$ might render P more available to plants [42].

The greater CEC of tailings when amended with high amounts of biosolids (20\%) is expected because organic materials are major sources of CEC in soils. Total acidities in isolated humus fractions separated from well-decomposed organic residues range from 300 to $1400 \mathrm{cmol}_{\mathrm{c}} \mathrm{kg}^{-1}$ humus [43].

4.2. Influence of Amendments and Earthworms on Mine Tailings. Earthworms can be classified into three ecological types: epigeic, endogeic, and anecic, based on their burrowing habits and habitat [44]. Dendrobaena veneta has been described as an epigeic earthworm (i.e., prefers organic materials such as organic litter layers or in compost). To the best of our knowledge, this is the first report of successful inoculation of Dendrobaena veneta addition to nonacidic sandy mine tailings. Earthworms generally do not do well in sandy substrates [22]; however, the tailings in this study were composed largely of feldspars, which are likely less abrasive than silica-based sands.

The survival of earthworms in amended nonacidic mine tailings (very fine sand) is quite significant because macrofaunal colonization of mine wastes is critical to the development of soils necessary to support plant establishment in postmine sites $[15,45]$. Earthworms are "ecosystem engineers" because they transform massive soil to favorable habitats for other organisms [46]. They intimately mix organic and inorganic materials into soil aggregates through ingestion and excretion [18]; they are the main producers of granular structure in many soils. We argue that the elongated spherical units observed in the microstructure of biosolidpulp sludge amended soils with earthworms (i.e., T2-W) represent the initial stages in the formation of soil aggregates. Similar microstructural units observed in acid mine tailings amended with organic residues are the precursor to the formation of granular structure [47]. Granular structure is ideal for plant growth because it promotes proper aeration, porosity and drainage. Soil aggregation is one of the best indicators of fertile soils because it bridges the physics and biochemistry of soil systems [48]. Shaw and Pawluk [49] reported that the formation of favourable soil structure is associated with the high concentrations of clay-bound sugars in fecal materials of earthworms.

We believe that the survival and activity of Dendobaena veneta in the mine tailings of this study were related to the proper combination of organic residues. The addition of immobilizer substrates was critical to the survival of this earthworm species. In addition, pulp sludge was a better substrate than sawdust to stimulate earthworm numbers and activities; this may have been due to more rapid and extensive decomposition (larger loss of $\mathrm{C}$ over the study period; also, greater reduction in $\mathrm{C} / \mathrm{N}$ ratio) and stimulation of microbial activity. These trends are consistent with the observation of greater earthworm vigour and size in an environment of low ammonium and likely large microbial populations (e.g., fungal biomass) to feed on. It is notable that the earthworms in this study were tolerant of the very high electrical conductivity $\left(\mathrm{EC}>10 \mathrm{dS} \mathrm{m}^{-1}\right)$ in several treatments by the end of the study. The significant positive correlation between soil EC and $\mathrm{NO}_{3}{ }^{-}-\mathrm{N}$ concentrations lead us to believe that high EC at the end of the study was largely due to the high $\mathrm{NO}_{3}{ }^{-}-\mathrm{N}$ concentrations. Although tolerant of these high EC values, the earthworms were lethargic, likely due to salt stress. The presence of plants in a field reclamation program would provide a sink for $\mathrm{NO}_{3}{ }^{-}-\mathrm{N}$ and should result in a reduction in EC, thereby providing a more favorable habitat for earthworms.

We conclude that proper amounts and types of organic residues in combination with earthworm addition may improve the chemical and microstructural properties of nonacidic mine tailings, producing a substrate conducive for plant establishment. This manufactured soil meets the definition of a Technosol [50]. Addition of earthworms with organic residues can be an option to safely manage residuals from numerous stockpiles and tailings ponds at many mined sites around the world. We recommend that future studies also consider the inoculation of earthworm species native to the mine location where tailings are obtained.

\section{Acknowledgments}

The authors acknowledge the Natural Sciences and Engineering Research Council, the Canada Research Chair program 
(Canada), and the Seed Grant Program at the University of Northern British Columbia for financial support to conduct the study. They also thank Clive Dawson at the BC Ministry of Environment (Victoria, BC) for conducting selected laboratory analyses. Dr. Paul Sanborn and Dr. Brian Menounos (both at UNBC) prepared thin sections and provided use of the petrographic microscope, respectively. Ron Martel of Mount Polley Mining Corporation, Norm Gobbi of the Prince George Wastewater Treatment Facility, and Kim Lentz of Canadian Forest Products Ltd. kindly provided in-kind support for this project.

\section{References}

[1] H. M. Conesa, Á. Faz, and R. Arnaldos, "Initial studies for the phytostabilization of a mine tailing from the CartagenaLa Union Mining District (SE Spain)," Chemosphere, vol. 66, no. 1, pp. 38-44, 2007.

[2] Northgate Mineral Corporation, "Technical report on the December 31, 2007 reserves for Kemess south mine," May 2008, http://www.northgateminerals.com/Theme/Northgate/ files/pdf/Technical/Kemess\%20South\%20re-filed $\% 20 \% 20$ May\%209\%20Technical\%20Report.pdf.

[3] H. Freitas, M. N. V. Prasad, and J. Pratas, "Plant community tolerant to trace elements growing on the degraded soils of São Domingos mine in the south east of Portugal: environmental implications," Environment International, vol. 30, no. 1, pp. 65-72, 2004.

[4] M. O. Mendez and R. M. Maier, "Phytostabilization of mine tailings in arid and semiarid environments: an emerging remediation technology," Environmental Health Perspectives, vol. 116, no. 3, pp. 278-283, 2008.

[5] M. H. Wong, "Ecological restoration of mine degraded soils, with emphasis on metal contaminated soils," Chemosphere, vol. 50, no. 6, pp. 775-780, 2003.

[6] J. Vangronsveld and S. Cunningham, "Introduction to the concepts," in In Situ Inactivation and Phytorestoration of Metal Contaminated Soils, J. Vangronsveld and S. Cunningham, Eds., pp. 1-15, Springer, Berlin, Germany; R.G. Landes, Georgetown, Tex, USA, 1998.

[7] W. H. O. Ernst, "Phytoextraction of mine wastes-options and impossibilities," Chemie der Erde, vol. 65, no. 1, pp. 29-42, 2005.

[8] P. Alvarenga, A. P. Gonçalves, R. M. Fernandes et al., "Reclamation of a mine contaminated soil using biologically reactive organic matrices," Waste Management and Research, vol. 27, no. 2, pp. 101-111, 2009.

[9] J. J. Camberato, B. Gagnon, D. A. Angers, M. H. Chantigny, and W. L. Pan, "Pulp and paper mill by-products as soil amendments and plant nutrient sources," Canadian Journal of Soil Science, vol. 86, no. 4, pp. 641-653, 2006.

[10] S. L. Brown, C. L. Henry, R. Chaney, H. Compton, and P. S. DeVolder, "Using municipal biosolids in combination with other residuals to restore metal-contaminated mining areas," Plant and Soil, vol. 249, no. 1, pp. 203-215, 2003.

[11] M. J. Shipitalo and J. V. Bonta, "Impact of using paper mill sludge for surface-mine reclamation on runoff water quality and plant growth," Journal of Environmental Quality, vol. 37, no. 6, pp. 2351-2359, 2008.

[12] D. A. N. Ussiri and R. Lal, "Carbon sequestration in reclaimed minesoils," Critical Reviews in Plant Sciences, vol. 24, no. 3, pp. 151-165, 2005.
[13] S. Brown, A. Svendsen, and C. Henry, "Restoration of high zinc and lead tailings with municipal biosolids and lime: a field study," Journal of Environmental Quality, vol. 38, no. 6, pp. 2189-2197, 2009.

[14] G. Tian, T. C. Granato, A. E. Cox, R. I. Pietz, C. R. Carlson Jr., and Z. Abedin, "Soil carbon sequestration resulting from longterm application of biosolids for land reclamation," Journal of Environmental Quality, vol. 38, no. 1, pp. 61-74, 2009.

[15] C. J. M. Ottenhof, Á. Faz Cano, J. M. Arocena, K. G. J. Nierop, J. M. Verstraten, and J. M. van Mourik, "Soil organic matter from pioneer species and its implications to phytostabilization of mined sites in the Sierra de Cartagena (Spain)," Chemosphere, vol. 69, no. 9, pp. 1341-1350, 2007.

[16] J. M. Arocena, J. M. van Mourik, M. L. M. Schilder, and Á. Faz Cano, "Initial soil development under pioneer plant species in metal mine waste deposits," Restoration Ecology, vol. 18, no. 2, pp. 244-252, 2010.

[17] P. Lavelle, T. Decaëns, M. Aubert et al., "Soil invertebrates and ecosystem services," European Journal of Soil Biology, vol. 42, no. 1, pp. S3-S15, 2006.

[18] C. A. Edwards and J. E. Bater, "The use of earthworms in environmental management," Soil Biology and Biochemistry, vol. 24, no. 12, pp. 1683-1689, 1992.

[19] M. M. Pulleman, J. Six, A. Uyl, J. C. Y. Marinissen, and A. G. Jongmans, "Earthworms and management affect organic matter incorporation and microaggregate formation in agricultural soils," Applied Soil Ecology, vol. 29, no. 1, pp. 1-15, 2005.

[20] S. S. Bhattacharya and G. N. Chattopadhyay, "Increasing bioavailability of phosphorus from fly ash through vermicomposting," Journal of Environmental Quality, vol. 31, no. 6, pp. 2116-2119, 2002.

[21] M. B. Postma-Blaauw, J. Bloem, J. H. Faber, J. W. van Groenigen, R. G. M. de Goede, and L. Brussaard, "Earthworm species composition affects the soil bacterial community and net nitrogen mineralization," Pedobiologia, vol. 50, no. 3, pp. 243-256, 2006.

[22] J. P. Curry, "Factors affecting the abundance of earthworms in soils," in Earthworm Ecology, C. A. Edwards, Ed., pp. 91-113, CRC Press, Boca Raton, Fla, USA, 2nd edition, 2004.

[23] B. A. Snyder and P. F. Hendrix, "Current and potential roles of soil macroinvertebrates (earthworms, millipedes, and isopods) in ecological restoration," Restoration Ecology, vol. 16, no. 4, pp. 629-636, 2008.

[24] C. A. Edwards, "The use of earthworms in the breakdown and management of organic wastes," in Earthworms in Waste and Environmental Management, C. A. Edwards and E. F. Neuhauser, Eds., pp. 21-31, SPB Academic Press, The Hague, the Netherlands, 1998.

[25] M. P. J. C. Marinussen, S. E. A. T. M. van der Zee, and F. A. M. de Haan, "Cu accumulation in the earthworm Dendrobaena veneta in a heavy metal $(\mathrm{Cu}, \mathrm{Pb}, \mathrm{Zn})$ contaminated site compared to $\mathrm{Cu}$ accumulation in laboratory experiments," Environmental Pollution, vol. 96, no. 2, pp. 227-233, 1997.

[26] D. G. Maynard, Y. P. Kalra, and J. A. Crumbaugh, "Nitrate and exchangeable ammonium nitrogen," in Soil Sampling and Methods of Analysis, M. R. Carter and E. G. Gregorich, Eds., pp. 71-80, CRC Press, Taylor and Francis, Boca Raton, Fla, USA, 2nd edition, 2008.

[27] D. Kroetsch and C. Wang, "Particle size distribution," in Soil Sampling and Methods of Analysis, M. R. Carter and E. G. Gregorich, Eds., pp. 713-725, CRC Press, Taylor and Francis, Boca Raton, Fla, USA, 2nd edition, 2008. 
[28] W. H. Hendershot, H. Lalande, and M. Duquette, "Soil reaction and exchangeable acidity," in Soil Sampling and Methods of Analysis, M. R. Carter and E. G. Gregorich, Eds., pp. 173178, CRC Press, Taylor and Francis, Boca Raton, Fla, USA, 2nd edition, 2008.

[29] J. J. Miller and D. Curtin, "Electrical conductivity and soluble ions," in Soil Sampling and Methods of Analysis, M. R. Carter and E. G. Gregorich, Eds., pp. 161-171, CRC Press, Taylor and Francis, Boca Raton, Fla, USA, 2nd edition, 2008.

[30] J. M. Bremner, "Nitrogen-total," in Methods of Soil Analysis, Part 3, Chemical Methods, D. L. Sparks et al., Ed., pp. 10851121, ASA-SSSA, Madison, Wis, USA, 1996.

[31] D. Curtin and C. A. Campbell, "Mineralizable nitrogen," in Soil Sampling and Methods of Analysis, M. R. Carter and E. G. Gregorich, Eds., pp. 599-606, CRC Press, Boca Raton, Fla, USA, 2nd edition, 2004.

[32] M. E. Sumner and W. P. Miller, "Cation exchange capacity and exchange coefficients," in Methods of Soil Analysis, Part 3, Chemical Methods, D. L. Sparks et al., Ed., pp. 1201-1229, ASA-SSSA, Madison, Wis, USA, 1996.

[33] S. Kuo, "Phosphorus," in Methods of Analysis, Part 3, Chemical Methods, D. L. Sparks et al., Ed., pp. 869-919, ASA-SSSA, Madison, Wis, USA, 1996.

[34] G. Stoops, Guidelines for Analysis and Description of Soil and Regolith Thin Sections, Soil Science Society of America, Madison, Wis, USA, 2003.

[35] StatSoft, Inc., "STATISTICA (data analysis software system), version 6," 2003, http://www.statsoft.com/.

[36] F. De Coninck, "Major mechanisms in formation of spodic horizons," Geoderma, vol. 24, no. 2, pp. 101-128, 1980.

[37] Canadian Council of the Ministers of the Environment (CCME, Canadian Environmental Quality Guidelines, Canadian Council of the Ministers of the Environment, Winnipeg, Canada, 2004.

[38] S. Brown, P. DeVolder, H. Compton, and C. Henry, "Effect of amendment C:N ratio on plant richness, cover and metal content for acidic $\mathrm{Pb}$ and $\mathrm{Zn}$ mine tailings in Leadville, Colorado," Environmental Pollution, vol. 149, no. 2, pp. 165$172,2007$.

[39] J. Frouz and A. Nováková, "Development of soil microbial properties in topsoil layer during spontaneous succession in heaps after brown coal mining in relation to humus microstructure development," Geoderma, vol. 129, no. 1-2, pp. 54 64, 2005.

[40] B. Chaves, S. De Neve, P. Boeckx, O. Van Cleemput, and G. Hofman, "Manipulating nitrogen release from nitrogen-rich crop residues using organic wastes under field conditions," Soil Science Society of America Journal, vol. 71, no. 4, pp. 12401250, 2007.

[41] R. Stehouwer, R. L. Day, and K. E. Macneal, "Nutrient and trace element leaching following mine reclamation with biosolids," Journal of Environmental Quality, vol. 35, no. 4, pp. 1118-1126, 2006.

[42] M. E. Essington, Soil and Water Chemistry: An Integrative Approach, CRC Press, Boca Raton, Fla, USA, 2004.

[43] F. J. Stevenson, Humus Chemistry: Genesis, Composition, Reactions, John Wiley \& Sons, Toronto, Canada, 1994.

[44] T. S. Perel, "Differences in lumbricid organization connected with ecological properties," in Soil Organisms as Components of Ecosystems, U. Lohn and T. Persson, Eds., pp. 56-63, Ecological Bulletin, Stockholm, Sweden, 1977.

[45] J. Frouz, V. Pižl, and K. Tajovský, "The effect of earthworms and other saprophagous macrofauna on soil microstructure in reclaimed and un-reclaimed post-mining sites in Central
Europe," European Journal of Soil Biology, vol. 43, no. 1, pp. S184-S189, 2007.

[46] C. G. Jones, J. H. Lawton, and M. Shachak, "Organisms as ecosystem engineers," Oikos, vol. 69, no. 3, pp. 373-386, 1994.

[47] A. Zanuzzi, J. M. Arocena, J. M. van Mourik, and Á. Faz Cano, "Amendments with organic and industrial wastes stimulate soil formation in mine tailings as revealed by micromorphology," Geoderma, vol. 154, no. 1-2, pp. 69-75, 2009.

[48] I. M. Young and J. W. Crawford, "Interactions and self-organization in the soil-microbe complex," Science, vol. 304, no. 5677, pp. 1634-1637, 2004.

[49] C. Shaw and S. Pawluk, "The development of soil structure by Oclolasion tyrtaceum, Aporreclodea turgida and Lumbricus terrestis in parent materials belonging to different textural classes," Pedobiologia, vol. 29, pp. 327-339, 1986.

[50] IUSS Working Group WRB, "World reference base for soil resources 2006. World soil resources," Report 103, FAO, Rome, Italy, 2006. 

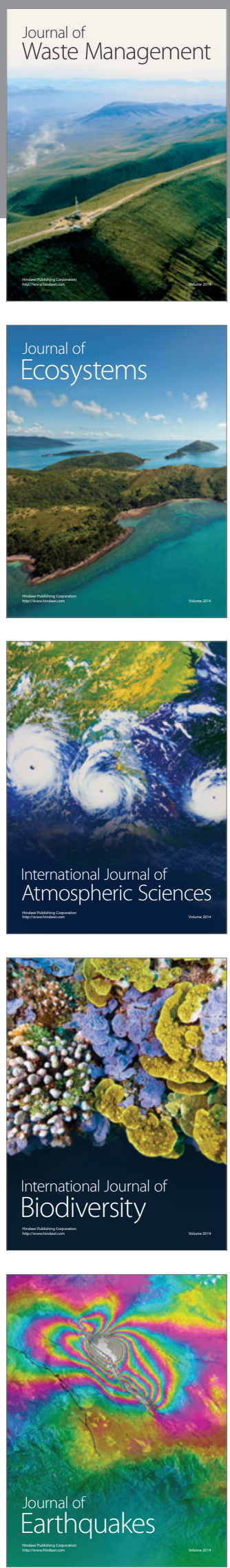
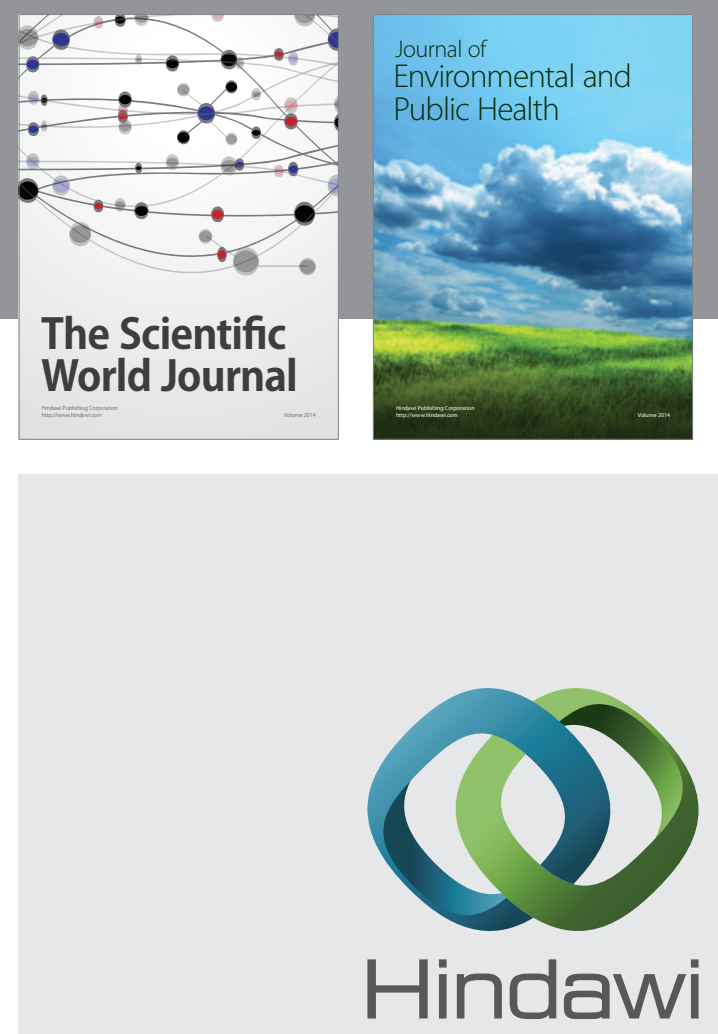

Submit your manuscripts at

http://www.hindawi.com
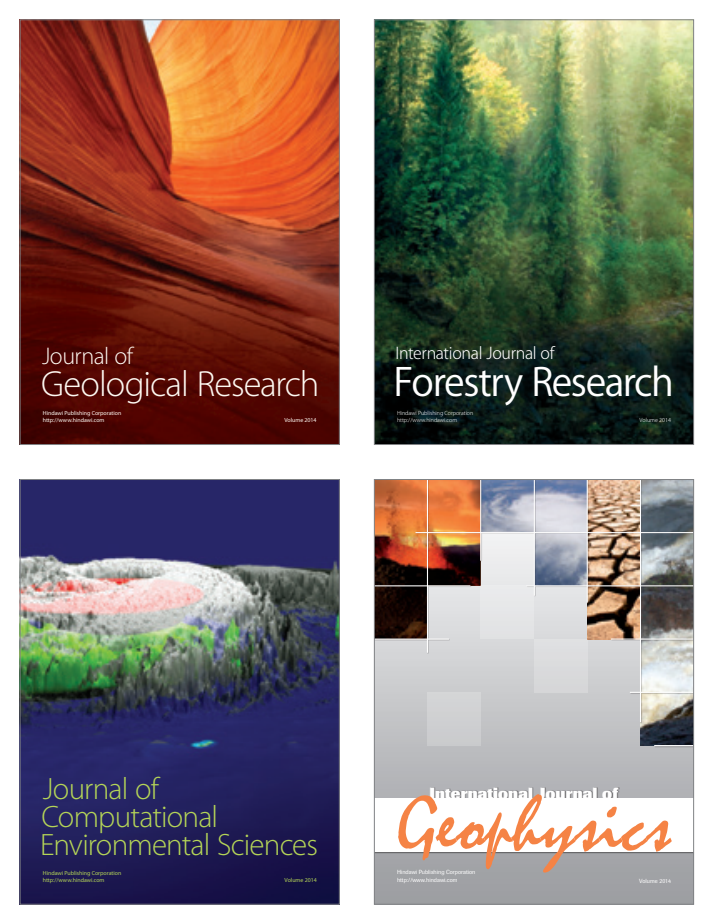
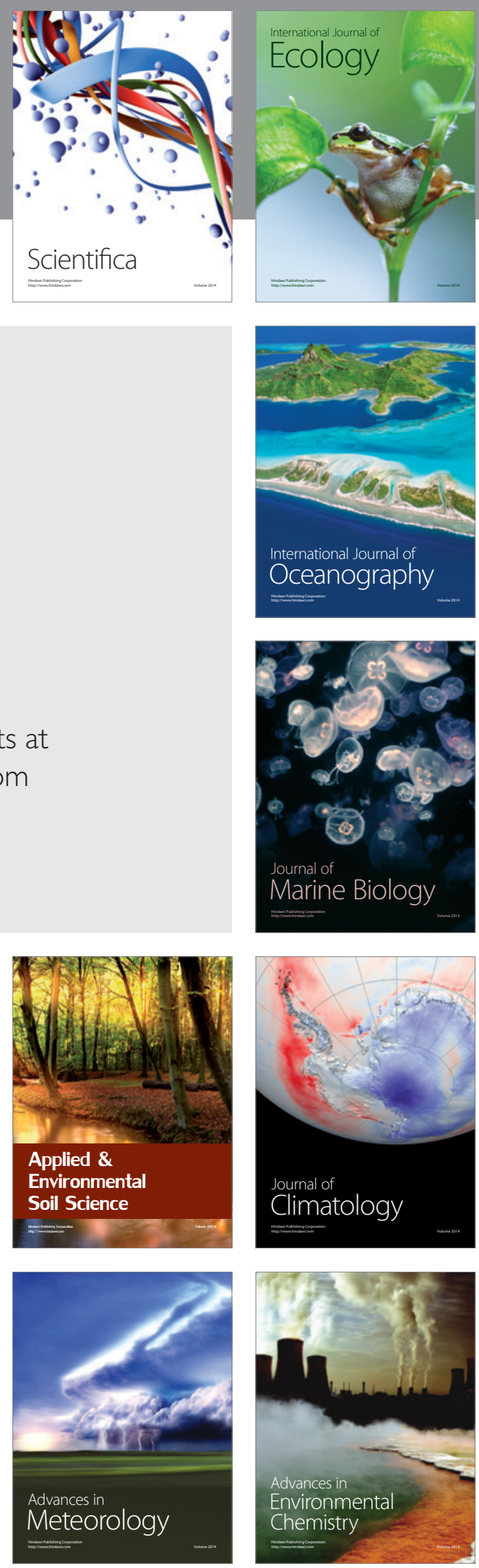